\title{
Erratum to: Psychosomatic complaints and sense of coherence among adolescents in a county in Sweden: a cross-sectional school survey
}

Bo Simonsson ${ }^{1,3^{*}}$, Kent W. Nilsson ${ }^{2}$, Jerzy Leppert ${ }^{2}$ and Vinod K. Diwan ${ }^{3}$

The Additional file 1 in this article [1] has been removed at the request of the copyright holder. Information about Antonovsky's short 13-item version of the Sense of Coherence scale is available at http://www.salutogenesis.hv.se/eng/SOC_questionnaire.19.html.

\begin{abstract}
Author details
${ }^{1}$ Department of Community Medicine, County Council of Västmanland, Västerås, Sweden. ${ }^{2}$ Centre for Clinical Research, Uppsala University, Central Hospital, Västerås, Sweden. ${ }^{3}$ Department of International Health (IHCAR), Karolinska Institute, Stockholm, Sweden.
\end{abstract}

Received: 3 November 2015 Accepted: 3 November 2015

Published online: 06 November 2015

\section{Reference}

1. Simonsson B, Nilsson KW, Leppert J, Diwan VK. Psychosomatic complaints and sense of coherence among adolescents in a county in Sweden: a cross-sectional school survey. BioPsychoSocial Medicine. 2008;2:4.

\footnotetext{
* Correspondence: bo.simonsson@ltv.se

'Department of Community Medicine, County Council of Västmanland, Västerås, Sweden

${ }^{3}$ Department of International Health (IHCAR), Karolinska Institute, Stockholm, Sweden

Full list of author information is available at the end of the article
}

Submit your next manuscript to BioMed Central and take full advantage of:

- Convenient online submission

- Thorough peer review

- No space constraints or color figure charges

- Immediate publication on acceptance

- Inclusion in PubMed, CAS, Scopus and Google Scholar

- Research which is freely available for redistribution 